10. Hanson PJV, Gor D, Clarke JR, et al. Contamination of endoscopes used in AIDS patients. Lancet 1989:86-88.

11. Hanson PJV, Gor D, Jeffries DJ, Collins JV. Elimination of high titre HIV from fibreoptic endoscopes. Gut 1990;31:657-659.

12. Hanson PJV, Gor D, Clarke JR, et al. Recovery of the human immunodeficiency virus from fibreoptic bronchoscopes. Thorax 1991:46:410-412.

13. Hanson PJV, Chadwick MV, Gaya H, Collins JV. A study of glutaraldehyde disinfection of fibreoptic bronchoscopes experimentally contaminated with M ycobacterium tuberculosis. J H osp Infect 1992;22:137-142.

14. Vesley D, Norlien KG, Nelson B, Ott B, Streifel AJ. Significant factors in the disinfection and sterilization of flexible endoscopes. A m J Infect Control 1992;20:291-300.

15. Collins FM. Bactericidal activity of alkaline glutaraldehyde solution against a number of atypical mycobacterial species. J A ppl Bacteriol 1986;61:247-251.

16. Collins FM. Kinetics of the tuberculocidal response by alkaline glutaraldehyde in solution and on an inert surface. J Appl Bacteriol 1986;61:87-93.

17. Collins FM. Use of membrane filters for measurement of mycobactericidal activity of alkaline glutaraldehyde solution. Appl Environ Microbiol 1987;53:737-739.

18. Ascenzi JM, Ezzell RJ, Wendt TM. A more accurate method for measurement of tuberculocidal activity of disinfectants. Appl Environ M icrobiol 1987;53:2189-2192.
19. Best M, Sattar SA, Springthorpe VS, Kennedy ME. Efficacies of selected disinfectants against M ycobacterium tuberculosis. J Clin M icrobiol 1990;28:2234-2239.

20. Cole EC, Rutala WA, Nessen L, Wannamaker NS, Weber DJ. Effect of methodology, dilution, and exposure time on the tuberculocidal activity of glutaraldehyde-based disinfectants. Appl Environ M icrobiol 1990;56:1813-1817.

21. Rutala WA, Cole EC, Wannamaker NS, Weber DJ. Inactivation of $M$ ycobacterium tuberculosis and Mycobacterium bovis by 14 hospital disinfectants. Am JMed 1991;91(3B):267S-271S.

22. Best M. Development of a combined carrier test for disinfectant efficacy. Thesis. Ottawa, Canada: University of Ottawa, 1994, p 65 .

23. Mbithi JN, Springthorpe VS, Sattar SA, Pacquette M. Bactericidal, virucidal, and mycobactericidal activities of reused alkaline glutaraldehyde in an endoscopy unit. J Clin M icrobiol 1993;31:2988-2995.

24. Collins FM, Montalbine V. Mycobactericidal activity of glutaraldehyde solutions. J Clin M icrobiol 1976;4:408-412.

25. Masferrer R, Marquez R Comparison of two activated glutaraldehyde solutions: Cidex solution and Sonacide. Respiratory Cure. 1977;22:257-262.

26. Hanson PJV, Jeffries DJ, Collins JV. Viral transmission and fibreoptic endoscopy. J Hosp Infect 1991;18:136-140.

\title{
GAO Releases Report on VA Hospitals and Use of Safer Needle Devices
}

\section{by Gina Pugliese, RN, MS Medical News Editor}

A GAO report to Congress, released late in 1994, indicated that Department of Veterans Affairs (VA) medical centers individually are responsible for acquiring medical devices, including safer needle and sharps devices. However, insufficient data are available in these medical centers to demonstrate the extent to which safer devices are needed and whether the devices will reduce the number of percutaneous injuries.

Further, the report noted there was a $19 \%$ decrease in reported needle injuries from 1992 to 1993 . However, VA officials did not know to what extent this decrease could be attributed to better use of universal precautions, safer devices, or underreporting of needle injuries. Infection control personnel at VA medical centers and clinical staff at the private hospitals told the GAO researchers that percutaneous injuries frequently go unreported and could be understated by as much as $75 \%$ because of underreporting. However, a current surveillance study conducted by three private hospitals and a VA medical center in San Francisco indicated that the reporting of percutaneous injuries can be improved substantially if immediate, confidential counseling and follow-up are available to the injured workers.

The report also noted that VA healthcare workers are at risk of lifethreatening diseases from a percutaneous injury involving HIV or hepatitisinfected blood. However, as of September 1994, there were no documented cases of VA healthcare workers being infected with HIV as a result of such an injury. The VA did not have any data on the number of healthcare workers that may have developed hepatitis from a percutaneous exposure, because this type of data is not maintained.

Acquisition of safer devices to prevent percutaneous injuries was found to vary by medical center, and the information needed to make informed procurement decisions was not always available. In 1993, 90 VA acute and nonacute medical centers spent about \$1.1 million to purchase 33 types of new and safer devices that FDA approved. However, several of the medical centers that did not purchase safer devices are in areas of high HIV prevalence.

Recommendations were for the Secretary of Veterans Affairs to require the Under Secretary of Health to 1) test ways to improve the reporting of percutaneous injuries and to develop a systemwide strategy to implement successful approaches; 2) fund pilot projects in which acute care medical centers acquire and test safer needle and sharps devices, and to determine their impact on incidence of injuries over a period of time; and 3) establish a communication network to disseminate information on the results of tests and studies involving safer devices to all medical centers and to others when requested.

FROM: GAO. VA health care: purchases of safer devices should be based on risk of injury. GAO/HEHS-9512; November 1994. 